\title{
PERILAKU MENGHISAP LEM (NGELEM) SEBAGAI TAHAP DINI PENGGUNAAN NARKOBA PADA REMAJA DI KOTA MAKASSAR
}

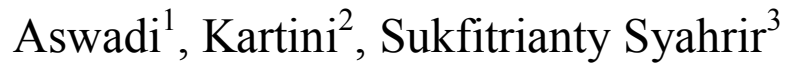 \\ ${ }^{1,2}$ Bagian Promosi Kesehatan Fakultas Kesehatan Masyarakat Universitas Pancasakti \\ ${ }^{3}$ Bagian Gizi Jurusan Kesehatan Masyarakat Universitas Negeri Alauddin Makassar
}

\begin{abstract}
ABSTRAK
Salah satu kelompok yang paling rentan terhadap penggunaan Napza adalah kelompok remaja, Mereka sangat rentan dengan penggunaan Napza inhalansia yang relatif murah dan mudah di dapat yaitu lem. Ngelem merupakan penggunaan Napza jenis lem dengan cara dihirup hingga kondisi tertentu dan berpotensi amat kuat untuk menimbulkan ketergantungan bagi pengguna. Penelitian ini bertujuan untuk mendapatkan informasi mengenai perilaku penggunaan Napza Inhalansia(ngelem) pada remaja di Kota Makassar. Jenis penelitian yang dilakukan adalah penelitian kualitatif denganrancangan fenomenologi. Informan dipilih dengan teknik snowball sampling, Pengumpulan data dilakukan dengan cara wawancara mendalam, melakukan observasi langsung dan focus group discussion ( $F G D$ ) kepada enam informan untuk mendapatkan informasi yang lebih rinci. Hasil penelitian menunjukkan, kerentanan individu seorang remaja menggunakan lem karena ingin memuaskan rasa ingin tahu (curiousity), untuk menghilangkan rasa capek dan stress dan membuat informan tidak merasakan lapar ketika seharian di jalanan, dan sebagai subtitusi ketika tidak mendapatkan Napza jenis shabu (simultaneous polydrug use). Kerentanan sosial seorang anak sehingga memilih keluar dari rumah terdiri dari beberapa faktor, yaitu kesulitan keuangan atau tekanan kemiskinan, ingin mencari kesenangan diluar rumah, serta ketidak harmonisan dalam rumah tangga/orang tua. Untuk upaya pencegahan perilaku "ngelem" hendaknya dilakukan mulai dari usia dini mengenai dampak dari perilaku "ngelem" dan diharapkan kepada orang tua (keluarga) untuk mengarahkan anak-anaknya dalam memilih teman-teman bergaul.
\end{abstract}

Kata Kunci: Perilaku, Menghisap Lem, Ngelem, Remaja

\section{PENDAHULUAN}

Masa remaja merupakan masa peralihan dari masa kanak-kanak menuju masa puber/dewasa Hartadi dalam Sumarlin (2012). Pada masa inilah umumnya dikenal sebagai masa, penuh energi, serba ingin tahu, belum sepenuhnya memiliki pertimbangan yang matang,mudah terpengaruh, nekat, berani, emosi tinggi, selalu ingin mencoba dan tidak mau ketinggalan. Pada masa-masa inilah remaja merupakan kelompok yang paling rawan berkaitan dengan penyalahgunaan NAPZA salah satunya yaitu penyalahgunaan lem (inhalen).

Perilaku menghisap lem merupakan 
bentuk perilaku menyimpang. Lem yang merupakan bahan untuk perekat suatu benda, disalahgunakan oleh anak remaja untuk perbuatan yang melanggar norma dan nilai tertentu. Menghisap lem adalah menghirup uap yang ada dalam kandungan lem tujuannya untuk mendapatkan sensasi tersendiri.

Diluar negeri perilaku menghisap lem dapat juga dijumpai. Salah satunya di negara Australia, yang terletak di Kota Alice Spring Cottrell-Boyce (2010). Dikota-kota besar di Indonesia, salah satunya kota Makassar, perilaku anak remaja menghisap lem dapat dijumpai. Penelitian yang dilakukan oleh Azriful (2016) menunjukkan bahwa sebagian besar umur anak jalanan yang melakukan aktivitas inhalasi (ngelem) yaitu 15-18 tahun yakni 29 (67,4\%) responden.

Berdasarkan hasil penelitian yang dilakukan oleh BNN bekerjasama dengan Pusat Penelitian Kesehatan Universitas Indonesia Tahun 2014, tentang Survei Nasional Perkembangan Penyalahgunaan Narkoba di Indonesia, diketahui bahwa angka prevalensi penyalahguna Napza di Indonesia telah mencapai 2,18\% atau sekitar 4.022.702 orang dari total populasi penduduk (berusia 10 - 59 tahun). Hasil penelitian ini menunjukkan adanya penurunan prevalensi penyalahgunaan Napza di Indonesia dari 2,23\% pada tahun 2011 menjadi $2,18 \%$ pada tahun
2014 (BNN RI, 2014).

Berdasarkan data dari badan narkotika nasional Sulawesi Selatan (BNN) bahwa rata-rata angka proyeksi prevalensi penyalahgunaan narkotika di Sulawesi Selatan sebesar 6\%. Pada tahun 2010 angka proyeksi prevalensi sebesar 2,04\% (121.773 orang) dan meningkat menjadi 2,08\% (125.730 orang) pada tahun 2011, pada tahun 2012 meningkat menjadi 2,14\% (131.200 orang), pada tahun 2013 meningkat menjadi 2,20\% (136.671 orang), dan diperkirakan meningkat menjadi 2,32\% (147.611 orang) pada akhir tahun 2015 jika tidak mendapat penanganan yang tepat.

Inhalansia merupakan salah satu dari jenis Napza dan mengandung zat kimiawi yang mudah menguap dan berefek psikoaktif. Umunya digunana oleh anak dibawah umur atau golongan kurang mampu/anak jalanan. Zat Inhalansia umumnya terkandung dalam barang yang lazim digunakan dalam rumah tangga sehari-hari salah satunya adalah lem (Kepmenkes RI No.422, 2010). Lem adalah alternatif lain yang digunakan anak jalanan untuk merasakan sensasi fly, mengingat kemungkinan untuk mendapatkan narkotika dan obat terlarang lainnya cukup sulit karena kondisi ekonomi dan legalitas dari barang tersebut.

Jenis lem yang digunakan dalam melakukan aktifitas "ngelem" yakni, lem jenis fox, aibon untuk mnimbulkan efek nyaman 
(fly), lem perabotan atau lem alat rumah tangga. Lem ini mengandung bermacammacam zat kimia yang sangat berbahaya jika dikonsumsi. Perilaku "ngelem", khususnya pada remaja merupakan salah satu cara untuk menghilangkan stress. Selain itu kebiasaan untuk "ngelem juga dipengaruhi oleh teman-teman yang lain sebagai bentuk dari solidaritas diantara anak-anak jalanan. "ngelem" juga seringkali dijadikan syarat untuk diterima dalam pergaulan ataupun komunitas tertentu.

Bahaya yang diakibatkan dari "nglem" ini dapat bermacam-macam dan terkadang pecandunya kebanyakan tidak mengetahui organ tubuh mana saja yang dapat terserang. Bahayanya tidak hanya menyerang organ tubuh seperti otak, jantung dan paruparu, bahkan virus pun akan lebih mudah masuk kedalam tubuh mereka. Tidak hanya menyerang fisik, melainkan mental, emosional dan spiritual mereka pun akan terganggu.

Uraian diatas menjelaskan bahwa perilaku penyalahgunaan lem (ngelem) merupakan salah satu masalah serius yang berakibat buruk pada kesehatan dan menimbulkan masalah sosial khususnya kelompok yang berisiko yaitu anak remaja. Sehingga peneliti tertarik ingin melakukan penelitiandengan mengkaji Perilaku Menghisap Lem (Ngelem) Sebagai Tahap Dini Penggunaan Narkoba Pada Kalangan Re- maja di Kota Makassar.

\section{METODE PENELITIAN}

Penelitian ini merupakan penelitian kualitatif dengan menggunakan pendekatan fenomenologi. Fenomenologi merupakan metode penelitian yang mencakup dan memaparkan makna atas fenomena pengalaman yang didasari oleh kesadaran yang terjadi pada individu (Emzir, 2011). Pengumpulan data diperoleh dengan tiga cara, yaitu data primer yang diperoleh dari hasil, $F_{O}$ cus Group Discussion (FGD),wawancara mendalam (Indepth Interview) dan Observasi secara langsung terhadap informan yang telah direkomendasikan oleh salah satu remaja yang sampai saat ini melakukan aktivitas "ngelem" yang bersedia untuk diwawancarai. Instrumen yang digunakan dalam penelitian adalah pedoman wawancara (Alat tulis, Tape Recorder dan Kamera). Data yang diperoleh diolah dengan menggunakan teknik matriks dan selanjutnya dilakukan dengan analisis isi (Content Analysis).

\section{HASIL PENELITIAN}

\section{Karakteristik Informan}

Informan penelitian ini terdiri dari 6 remaja berjenis kelamin laki-laki. Variasi umur 14 sampai dengan 18 tahun, dan hampir semua informan mempunyai kegiatan ekonomi (bekerja) dan masih 
memiliki hubungan dengan keluarga. Secara umum semua informan penah mengenyam pendidikan formal, tamat SD 2 orang, tamat SMP 3 orang dan SMA 1 orang. Terdapat satu informan yang menggunakan lem (ngelem) selama satu bulan, dua informan yang menggunakan lem selama satu tahun, satu informan yang menggunakan lem selama dua tahun, satu informan menggunakan lem selama tiga tahun dan satu informan mengunakan lem selama empat tahun.

\section{Kerentanan Individu}

Usia pertama kali menggunakan lem berbeda-beda namun kebanyakan dari mereka mulai mungganakan lem pada usia 16 tahun, terdapat juga informan yang telah menggunkan lem sejak usia 14 tahun, serta dalam jangka pemakaian berbeda-beda pula mulai dari pemakaian 1 bulan terakhir sampai pemakaian 4 tahun.

"Saya menggunakan lem sejak kelas dua SMP ka, kira-kira umur-umur 14 tahun. Jadi saya sudah bertahuntahunmi mengonsumsi lem".

$$
\text { D, laki-laki, } 18 \text { Tahun }
$$

Adapula informan yang menggunakan lem sejak umur 14 tahun, dalam lama penggunaan satu bulan terakhir.

"Baruka saya menggunakan lem sejak satu bulan yang lalu"

$$
\text { C, laki-laki,14 Tahun }
$$

Terdapat beberapa alasan yang berbeda mengapa mereka menggunakan lem, yaitu informan menggunakan lem/ngelem untuk megobati rasa penasaran, untuk menghilangkan rasa capek dan stress, dan rasa lapar bagi informan serta satu informan mengaku lem digunakan sebagai subtitusi ketika tidak mendapatkan shabu. Seperti pada kutipan berikut ini:

"Itu lem saya gunakan kalau lagi streskas. atau capekka mengamen, karena lem mampu menghilangkan rasa capek."

A, laki-laki, 17 tahun.

Lain halnya denga $\mathrm{B}$, dia menggunakan lem karena sebelumnya dia telah mengalami kecanduan terhadap Napza jenis shabu. Untuk mengimbangi konsumsi terhadap shabu atau agar tetap merasakan fly ketika tidak mendapatkan atau tidak memiliki uang untuk membeli shabu, B menggunakan lem sebagai pengganti Shabu.

"Lem saya gunakan sebagai pengimbang kalau saya tidak mendapatkan Shabu karena shabu susah di dapat dan mahalki harganya. Jadi ketika tidak ada uangku untuk beli shabu, saya menggunakan lem".

B, laki-laki, 17 tahun.

Pada saat menggunakan lem (ngelem) informan merasakan sensasi yang memabukkan seperti melayang, mimpi, terdengar suara teriakan didekat telinga, nyaman/tenang dan tidak merasa lapar, sehingga informan ingin terus menerus menggunakan lem.

"Ketika ngelem perasaan itu seperti bermimpi, terus ketika ngelem saya juga tidak pernah merasakan lapar, 
namun ketika efek zat lem sudah hilang perasaan langsung lapar sekali tetapi makanan susah di telan".

$$
\text { F, laki-laki,15 Tahun. }
$$

Hasil wawancara tersebut di dukung oleh hasil FGD (focus group discussion) dimana perasaan yang umum dirasakan informan ketika ngelem adalah perasaan seperti bermimpi, melayang, merasakan ada teriakan-teriakan ditelinganya, serta ketika ngelem infoman tidak pernah merasakan lapar.

Menurut informan, dia menggunakan lem agar semua beban fikirannya akan hilang, sehingga dia merasakan perasaan yang tenang, dia juga mengunakan lem agar tetap kuat dan semangat ketika sedang bekerja. Hal tersebut dirasakan pula oleh informan $\mathrm{F}$, dia merasa lebih percaya diri dan kuat ketika mengamen, serta merasa tidak lapar ketika menggunakan lem. sesuai dengan hasil wawancara berikut:

"Kalau sudahka ngelem perasaanku itu terasa kuat untuk pergi mengamen, saya merasa percaya diri menyanyi-menyanyi, tidak merasa lapar, begitu manfaat yang saya rasa ketika ngelem".

F, laki-laki, 15 tahun.

Informan menyatakan merasakan tanda kecanduan yang ada dalam dirinya setelah penggunaan lem, karena jika informan tidak menggunakan lem maka akan muncul gejala-gejala putus obat (withdrawal symptoms). Gejala yang dirasakan meliputi: kepala terasa pusing, perasaan tidak enak ketika bernafas tanpa mencium bau lem, melakukan/mencoba alternatif lain ketika tidak memperoleh lem, seperti mencampur gabus dengan bensin kemudian dihisap. ketika tidak ngelem, informan mersa ingin terus meludah, ketika tidak ngelem, inforan merasa gatal-gatal pada hidung, ketika tidak ngelem, infoman merasa lemas, dan seluruh badan terasa sakit.

"Perasaan terasa aneh kalau bernafaska tanpa mencium bau lem. Kemudian kalau tidak ngelem maka kepala akan terasa pusing. Itu yang membuat saya tidak tahan tidak ngelem. Terkadang ketika tidak ada uang untuk membeli lem dan saya sudah tidak tahan ingin ngelem, maka saya menggunakan gabus kemudian di campur bensin. Setelah itu di hisap seperti menggunakan lem. Rasanya juga enak, mirip dengan lem".

D, laki-laki, 18 tahun.

Tanggapan informan tehadap dampak yang dirasakan setelah mengalami kecanduan, mereka merasakan dampak lebih dominan pada dampak fisik, seperti: kepala terasa pusing jika tidak mengkonsumsi, nafsu makan terganggu (sistem percernaan terganggu), informan merasakan sakit seluruh badan ketika tidak ngelem.

"Saya merasa seluruh badan terasa sakit, perasaan lemas, kemudian saya tidak merasakan lapar, tetapi kalau hilangmi efek lem maka akan langsung terasa lapar namun itu makanan tidak mau turun/dicerna. 
Itu dampak lem yang saya rasakan".

A, laki-laki, 17 tahun.

Informan juga mengalami dampak sosial dari perilaku ngelem, karena kecanduan, informan tidak bisa lepas dari lem sehingga informan lebih sering menjauh dari lingkungan keluarga untuk menghindari kecurigaan keluarga terhadap perilakunya, serta informan harus memaksa dirinya selalu mencari uang untuk kebutuhannya tehadap lem.

"Sakit kepalaku ketika tidak menggunakanka lem. Jadi, saya harus selalu mencari uang untuk pembeli lem, dan saya selalu berusaha jauhjauh dari keluarga supaya mereka tidak megetahui perilaku saya".

(F, Laki-laki, 15 tahun.

\section{Kerentanan Sosial}

Kerentanan sosial dalam penelitin ini mengacu pada latar belakang hubungan komunikasi informan dengan orang tua dan angota keluarga lainnya, pergaulan dengan teman sebaya, serta bagaimana informan menerima atau tidak menerima ajakan teman untuk menggunakan lem.

Bedaraskan hasil wawancara mendalam mengenai hubungan komunikasi remaja dengan orang tua dan anggota keluarga lainnya, komunikasi informan dengan keluarga cukup beragam, terdapat informan yang memiliki komunikasi yang baik, ada pula informan yang tidak memiliki komunikasi yang baik. Hal ini sesuai dengan hasil wawancara berikut:

"Komunikasi saya dengan keluarga cukup baik, dan kalau tidak pulang kerumah dalam beberapa hari mereka selalu mencari dan mengajak saya pulang. Terus orang tua dan keluarga juga selalu memberikan nasihat kkalau seringka keluar malam”.

$$
\text { A, laki-laki,17 Tahun. }
$$

Terdapat pula informan keluar dari rumah karena tidak memiliki komunikasi yang baik dengan orang tua. Hal ini sesuai dengan hasil wawancara berikut:

"Hal yang membuat saya tidak suka tinggal di rumah itu karena ibu saya selalu marah-marah dan suka memarahi saya kalau adaka di rumah. Jadi itumi saya jarang pulang kerumah".

$$
\text { D, laki-laki,18 Tahun. }
$$

Pergaulan dengan teman sebaya memberikan kontribusi yang sangat besar dalam pembentukan perilaku seseorang. Berdasarkan hasil wawancara mendalam yang dilakukan peneliti, semua informan bergaul dengan teman sebaya yang menggunakan lem serta juga bergaul dengan teman sebaya yang tidak menggunkan lem dan mereka tetap menjaga pertemanan mereka meskipun dalam pertemanannya ada yang menggunalan lem dan ada yang tidak menggunakan lem. sesuai dengan hasil wawancara berikut:

"Saya teman-temanku ada yang pakai lem, dan ada juga tidak menggunakan lem. Tapi meskipun begitu, kita selauji sama-sama bergaul, karena ketika kita bersama 
semua akan terasa menyenangkan".

$$
\text { B, laki-laki, } 17 \text { tahun. }
$$

Hal tersebut didukung oleh hasil observasi bahwa:

"Remaja yang mempunyai pekerjaan sebagai pengamen, mereka selalu mengamen bersama-sama, membagi hasil yang di peroleh dari mengamen, namun beberapa remaja menggunakan sebagian uang tersebut untuk membeli lem, dan sebagian yang tidak ngelem, menggunakan membeli makanan dan mereka tetap berbagi dalam hal makanan, mereka yang tidak ngelem, tidak mempermasalah kan perilaku ngelem dari temannya".

Observasi, Agustus 2018.

Perilaku penggunaan Napza inhalasia (ngelem) pada remaja juga di bentuk dari pengaruh teman sebaya yang terlebih dahulu telah menggunakan lem, Informan mengunakan lem karena ajakan dari teman-teman mereka, dengan tawaran kalau lem mampu menghilangkan stress, mampu menghilangkan lapar, membuat perasaan jadi melayang, namun terdapat juga informan yang menggunakan lem bukan karena ajakan dari teman-temannya, dia tertarik melakukan perilaku ngelem karena adanya rasa penasaran ingin mencoba setelah melihat atau observasi perilaku dari temannya.

"Saya menggunakan lem berawal dari ajakan teman-teman, mereka menawarkan karena lem mampu menghilangkan stress, menghilangkan rasa lapar dan membuat perasaan melayang, kemudian saya mecoba menggunakan lem".

C laki-laki,14 Tahun.

Informan menyatakan bahwa perilaku penggunaan lemnya (ngelem) berawal dari pengaruh atau ajakan dari temannya sendiri, dengan tawaran bahwa lem bisa mengilangkan stress, menghilangkan lapar serta dapat membuat perasaan melayang.

Hasil wawancara mendalam yang dilakukan terhadap keenam informan, semua informan menyatakan bahwa perilaku ngelemnya tidak di ketahui oleh keluarga mereka, keluarga hanya mengetahui perilaku berisiko lainnya yang dilakukan informan, seperti merokok. Informan melakukan perilaku penggunaan lem (ngelem) diluar rumah, atau secara sembunyisembunyi agar keluarga tidak mengetahui, dengan alasan jika keluarga mengetahui mereka akan di marahi oleh keluarga mereka.

"Kedua orang tua saya tidak mengetahui bahwa saya sering menghisap lem namun,kalau merokok keluarga tahu karena mereka sering melihat dan saya juga sering merokok dirumah".

$$
\text { B, laki-laki, } 17 \text { tahun. }
$$

Informan menggunakan lem secara tersembunyi dari keluarga mereka dengan alasan karena takut keluarga akan marah kepadanya.

"Mama tidak mengetahui kalau 
saya menghisap lem, karena saya menggunakannya secara sembunyisembunyi dan jauh dari rumah. Karena saya takut ketika mama mengetahui perilaku saya, pasti dia akan marah kepada saya".

A, laki-laki, 17 tahun.

Informan tidak pernah menceritakan dan memperlihatkan perilaku ngelemnya kepada keluarga dengan alasan takut keluarga akan marah kepadanya, keluarga dari informan juga tidak pernah memperhatikan perilaku-perilku berisiko dan menyimpang yang informan lakukan ketika berada di jalan.

\section{PEMBAHASAN}

Perilaku menghisap lem merupakan bentuk perilaku menyimpang. Mengingat kemungkinan untuk mendapatkan narkotika dan obat-obatan terlarang tersebut cukup sulit karena masalah ekonomi. Sebagai alternatif lain, informan menggunakan zat adiktif yang ada disekitarnya dan mudah dijangkau seperti lem. Lem yang merupakan bahan untuk perekat suatu benda, disalahgunakan oleh anak remaja. Jenis lem yang digunakan dalam melakukan aktifitas "ngelem" yakni, lem jenis fox. Lem ini mengandung bermacam-macam zat kimia yang sangat berbahaya jika dikonsumsi. Menghisap lem adalah menghirup uap yang ada dalam kandungan lem tujuannya untuk mendapatkan sensasi tersendiri atau efek nyaman (fly).

\section{Kerentanan Terhadap Perilaku Ngelem}

Usia responden saat pertama kali menggunakan lem dan lama menggunakan diperoleh informasi bahwa Informan menggunakan lem/ngelem pada usia 14 - 16 tahun. Karena usia remaja merupakan usia yang masih rentang terhadap penyalahgunaan narkoba karena pada usia remaja tingkat emosi dan mental masih sangat labil, sehingga para remaja mudah terpengaruh ke dalam perilaku menyimpang. Penelitian ini sejalan dengan penelitian yang dilakukan oleh Chomariah (2015) tentang perilaku menghisap lem pada remaja yang mengatakan bahwa dari delapan sampel yang diteliti memiiki rentang umur 15-21 tahun.

Informan menggunakan lem untuk megobati rasa penasaran, lem sangat terjangkau dan membuat tetap membuat fly layaknya Napza jenis lainnya, untuk menghilangkan rasa capek dan stress serta rasa lapar yang dialami informan, serta satu informan mengaku lem digunakan sebagai cadangan ketika tidak mendapatkan shabu. Penelitian ini sejalan dengan penelitian yang dilakukan oleh Chomariah (2015) bahwa perilaku menghisap lem merupakan salah satu tindakan yang dilakukan oleh anak remaja di Kelurahan Sri meranti sebagai obat untuk penenang pikiran sementara. Dengan cara tersebut, mereka dapat merasakan sensasi, halusinasi bahkan fly yang dapat membuat pikiran mereka menjadi 
tenang dan tidak adanya persoalan hidup yang mereka rasakan.

Informan menggunakan lem/ngelem sebagai solusi jangka pendek atau sesaat akibat adanya tekanan-tekanan yang dialami. Misalnya tekanan pekerjaan, tekanan dari kondisi ekonomi dan tekanan dari permasalahan keluarga. Dan mereka membuktikan pada diri mereka bahwa ngelem mampu mengendalikan semua tekanantekanan yang ada dalam dirinya. Penelitian yang dilakukan oleh Adrian B. Kelly, 2015. terhadap siswa SMA menunjukkan bahwa tekanan psikologi memicu untuk penggunaan Napza secara bersama (polydrug), dimana tekanan tersebut berasal dari keluarga, status ekonomi atau kemakmuran.

Berdasarkan hasil penelitian, informan merasakan bahwa lem mampu menghilangkan stress, hal ini terjadi karena kandungan Lysergic Acid Diethyilamide $(L S D)$ yang terdapat pada lem. Dalam sel otak terdapat bermacam-macam zat kimia yang disebut neurotransmitter. Zat kimia ini bekerja pada sambungan sel saraf yang satu dengan sel saraf lainnya (sinaps). Beberapa di antara neurotransmitter itu mirip dengan beberapa jenis narkoba. Semua zat psikoaktif (narkotika, psikotropika dan bahan adiktif lain) dapat mengubah perilaku, perasaan dan pikiran seseorang melalui pengaruhnya terhadap salah satu atau be- berapa neurotransmitter. Neurotransmitter yang paling berperan dalam terjadinya ketergantungan adalah dopamine serta serotonin.

Menurut Setiawan dalam Sulaiman (2015), Efek yang ditimbulkan dari menghirup uap lem itu sendiri hampir mirip dengan jenis narkoba yang lain yakni menyebabkan halusinasi, sensasi melayanglayang serta rasa tenang sesaat meski kadang efeknya bisa bertahan hingga 5 jam sesudahnya. Efek lain yang bisa ditimbulkan dari kegiatan ngelem ini sendiri antara lain adalah tidak merasakan lapar meskipun sudah waktunya makan karena ada penekanan sensor lapar di susunan saraf di otak.

Sensasi yang di rasakan informan dari ngelem membuat informan merasakan bahwa lem memiliki manfaat jika terus di gunakan (dihisap), informan merasakan manfaat dari ngelem yaitu membuat perasannya tenang ketika sedang mendapatkan masalah atau ketika mereka lelah seharian bekerja dijalan, menghilangkan rasa lapar, membuat badan jadi kuat, serta meningkatkan kepercayaan diri.

Seseorang mengalami ketergantungan pada zat umumnya melalui suatu proses perkembangan. Pertama orang yang besangkutan harus mempunyai sikap positif terhadap obat tersebut, kemudian mulai bereksperimen dengan menggunakannya, 
mulai menggunakannya secara teratur, menggunakannya secara berlebihan dan terakhir menyalahgunakannya atau tergantung secara fisik padanya (Davidson, 2012).

Informan menyatakan merasakan tanda kecanduan yang ada dalam dirinya setelah penggunaan lem. Karena jika informan tidak menggunakan lem maka akan muncul gejala-gejala putus obat (withdrawal symptoms)yang merupakan gejala-gejala yang muncul ketika dihentikannya pemakaian Napza tersebut. Gejala yang dirasakan meliputi: kepala terasa pusing, perasaan tidak enak ketika bernafas tanpa mencium bau lem, melakukan/ mencoba alternatif lain ketika tidak memperoleh lem, seperti mencampur gabus/ Styrofoamdengan bensin, kemudian dihisap. Ketika tidak ngelem, informan mersa ingin terus meludah, ketika tidak ngelem, informan merasa gatal-gatal pada hidung, ketika tidak ngelem, infoman merasa lemas, dan seluruh badan terasa sakit.

Penelitian ini sejalan dengan hasil penelitian yang dilakukan oleh Tamrin (2013) tentang perilaku ngelem, Informan mengalami gejala-gejala putus zat apabila tidak memakai atau mengkonsumsi lem. Adapun yang diarasakan informan jika mengalami gejala-gejala putus zat seperti, pusing dan gelisah yang membuat mereka untuk terus mencari lem agar dapat melakukan aktivitas "ngelem" yang membuat mereka mengalami ketergantungan.

Ketergantungan informan terhadap lem memberikan dampak negatif. Dampak yang dirasakan setelah mengalami kecanduan, mereka merasakan dampak lebih dominan pada dampak fisik, seperti: kepala terasa pusing jika tidak mengkonsumsi, nafsu makan terganggu (sistem percernaan terganggu), informan merasakan sakit seluruh badan ketika tidak menghisap lem.

Informan juga mengalami dampak soial dari perilaku ngelem, karena kecanduan, informan tidak bisa lepas dari lem sehingnga informan lebih sering menjauh dari lingkungan keluarga untuk menghindari kecurigaan keluarga terhadap perilakunya, serta informan harus memaksa dirinya selalu mencari uang untuk kebutuhannya tehadap lem.

Ngelem merupakan solusi jangka pendek atas masalah yang dihadapi informan. Mereka merasakan dengan ngelem semua masalah dan tekanan mapu mereka lupakan, namun karena kenikmataan sesaat mereka harus menanggung efek jangka panjang dari perilaku ngelem.

Kerentanan Sosial

Kerentanan sosial seorang remaja memlilih keluar dari rumah terdiri dari beberapa faktor. Berdasarkan hasil penelitian remaja memilih keluar dari rumah karena alasan ingin mencari nafkah, ingin mencari kesenangan diluar rumah dengan berkumpul 
bersama teman-teman, serta ketidak harmonisan dalam rumah tangga/orang tua. Penelitian ini sejalan dengan penelitian Tamrin (2013) diperoleh informan mendapatkan kurang perhatian dari keluarga terutama kurang perhatian dari kedua orang tua yang sibuk dengan pekerjaannya, sehingga informan mencoba untuk "ngelem"

Perhatian dan kasih sayang keluarga sangat berperan dalam pembentukan perilaku anak, namun jika seseorang anak tidak memiliki hubungan keluarga yang harmonis maka anak akan cenderung mencari tempat dimana dia mendapatkan perhatian, ketenangan dan kesenangan di luar rumah seperti di jalan dan bergaul dengan anak jalanan lainnya, teman sebaya yang membuat dirinya merasa dihargai dan membuat anak merasa memeroleh kesenangan dan ketenangan memalui teman sebayanya.

Teman sebaya merupakan tempat utama dalam seorang anak bersosialisasi. Lingkungan juga dihuni oleh orang-orang yang memiliki perilaku negatif dan anti sosial yang bersifat menyimpang. Hal tersebut dapat menimbulkan reaksi emosional buruk bagi anak-anak yang labil jiwanya sehingga anak menjadi mudah terpengaruh oleh pola tindakan menyimpang (Mulyadi, 2013). Dengan demikian, anak yang tinggal di lingkungan yang menyim- pang kemungkinan besar akan memiliki perilaku menyimpang pula yang sama halnya dengan perilaku orang-orang yang ada di lingkungannya.

Mereka melakukan perilaku ngelem karena adanya pengaruh dari kelompok atau teman sebaya. Berdasarkan hasil wawancara, semua informan menggunakan lem berasal dari ajakan teman sepergaulan, dan rasa penasaran melihat perilaku ngelem temannya. Seperti observasi yang dilakukan peneliti, informan ngelem bersama teman-temannya dan sebagian besar mereka mengikuti perilaku, pakaian, etika dan norma yang diterapkan oleh teman-teman mereka atau kelompok.

Remaja memiliki kerentanan sosial untuk menggunakan lem dikarenakan adanya ketidak harmonisan di dalam keluarga misanya perceraian orang tua. Informan setelah turun kejalan, mereka mulai menggunakan lem, mereka menggunakannya karena salah satu alasannya untuk menghilangkan beban fikiran, dan terdapat informan yang menjadikan perceraian orang tua sebagai beban fikiran karena dengan perceraian orang tua yang dia alami sehingga dia harus putus sekolah dan turun kejalan untuk mencari nafka karena setelah perceraian orang tuanya dia sudah tidak di nafkahi oleh ayahnya.

Penelitian ini sejalan dengan peneli- 
tian yang dilakukan oleh Yusuf (dalam Rahayu, 2010) yaitu keluarga merupakan salah satu penyebab yang dapat mempengaharui perilaku menyimpang pada remaja. Kondisi keluarga yang dimaksud yaitu orang tua yang terlalu sibuk dengan pekerjaannya, perselisihan atau konflik orang tua maupun antar anggota keluarga lainnya, perceraian orang tua.

\section{KESIMPULAN}

Kerentanan individu seorang remaja menggunakan lem karena megobati rasa penasaran akan sensasi yang diperoleh dari ngelem, untuk menghilangkan rasa capek dan stress dan membuat informan tidak merasakan lapar ketika seharian di jalanan bekerja sebagai pengamen dan kuli bangunan, serta lem digunakan sebagai subtitusi ketika tidak mendapatkan shabu (polydrug users). Kerentanan sosial seorang remaja sehingga memlilih keluar dari rumah terdiri dari beberapa faktor, yaitu ingin mencari uang/nafkah, ingin mencari kesenangan diluar rumah dengan berkumpul bersama teman-teman sebaya, serta ketidak harmonisan dalam rumah tangga/orang tua.

\section{SARAN}

Untuk upaya pencegahan perilaku "ngelem" hendaknya dilakukan mulai dari usia dini mengenai dampak dari perilaku "ngelem" dan diharapkan kepada orang tua (keluarga) untuk mengarahkan anakanaknya dalam memilihteman-teman bergaul yang tepat agar tidak terjerumus dalam perilaku "ngelem".

\section{DAFTAR PUSTAKA}

Azriful, Ibrahim A.Irviani, Sulaiman Yuliana. 2016.Gambaran Pengguna Narkoba Inhalasi (Ngelem) Pada Anak jalanan di Kota Makassar Tahun 2015.Al-Sihah Public Health Science Journal. Volume 8, Nomor 1, Januari-Juni 2016.

BNN RI. (2014). Laporan Akhir Survei Nasional PerkembanganPenyalahguna NarkobaTahun Anggaran 2014. Jakarta: Badan Narkotika Nasional RI.

Chomariah, Siti. 2015. "Perilaku Menghisap Lem pada Anak Remaja (Studi Kasus di Kota Pekanbaru). Skripsi. Riau. Fakultas Ilmu Sosial Ilmu Politik Universitas Riau.

Cottrell-Boyce J. (2010). The Role Of Solvents In The Lives of Kenyan Street Children: An Ethnographic Perspective. School of Oriental and African Studies, University of London.

Davidson G.C.dkk. (2012). Psikologi Abnormal edisi ke-9. Jakarta: rajawali Pers.

Emzir. 2011. Metode Penelitian Kualitatif Analisis Data. Jakarta: Grafindo Persada.

Kementerian Kesehatan Republik Indonesia.(2010). Pedoman Penatalaksanaan Medik GangguanPenggunaan Napza.Jakarta: Direktorat 
Jendral Bina Pelayanan Medik Kemenenterian Kesehatan RI.

Mulyadi M. (2013). "Perilaku NgelemPada Anak Jalanan (Studi Anak Jalanan di Jalan D.I Pandjaitan Km. Ix, Kota Tanjungpinang".Skripsi.Fakultas Ilmu Sosial dan Ilmu Politik Universitas Maritim Raja Ali Haji Tanjungpinang.

Rahayu . 2010. Penyalahgunaan Napza Dapat Menghancurkan Generasi
Muda. Universitas sumatera utara.

Sumarlin, R. 2012. Perilaku Kinformitas Pada Remaja Yang Berada di Lingkungan Peminum Alkohol. Universitas Gunadarma, Jakarta

Tamrin M. et al.(2013). "Studi Perilaku "Ngelem" pada Remaja di Kecamatan Paleteang Kabupaten Pinrang" Skripsi. Makassar: Fakultas Kesehatan Masyarakat Universitas Hasanuddin. 